\title{
TINGKAT PEMAHAMAN KEPALA SEKOLAH, GURU, DAN KOMITE SEKOLAH TERHADAP IMPLEMENTASI STANDAR PENGELOLAAN PENDIDIKAN DI SEKOLAH DASAR
}

\section{UNDERSTANDING OF SCHOOL HEADERS, TEACHERS, AND SCHOOL COMMITTEES TOWARD IMPLEMENTATION OF EDUCATION MANAGEMENT STANDARDS IN PRIMARY SCHOOLS}

\author{
Arsyad Djamalludin Palettei \\ STKIP Muhammadiyah Bogor \\ Jl. Raya Leuwiliang No.106 Bogor \\ E-mail: arsyaddjamaluddin@gmail.com \\ Wahyu Bagja Sulfemi \\ STKIP Muhammadiyah Bogor \\ Jl. Raya Leuwiliang No.106 Bogor \\ E-mail: wahyubagja@gmail.com \\ Yusfitriadi \\ Lembaga Studi Visi Nusantara Bogor \\ Bumi Cibinong Endah Blok. D8.No.11. Bogor \\ E-mail: yoes_fitriadi@yahoo.com
}

Naskah diterima tanggal: 06-07-202, disetujui tanggal: 11-03-2021

\begin{abstract}
This study aims to determine the level of understanding of school principals, teachers, and committees as if in the implementation of education management standards by primary and secondary education units, especially in public elementary schools. This research uses a descriptive quantitative method. The data were obtained from accredited $A$ and $B$ elementary schools in urban areas in eight districts/cities in West Java, with the sampling technique using purposive sampling. The primary data in this study were the knowledge of school principals, teachers, and school committees of education management standards, while secondary data were documents of the implementation of education management standards. Data analysis using descriptive statistics. The results showed, firstly that the understanding of school principals and teachers of education management standard regulations was quite understanding, while the school committee had a lack of understanding of the education management standard regulations, secondly based on the results of data analysis that, principals and teachers considered the implementation of school governance. the category was sufficient according to the education management standard, while according to the school committee, the implementation of school governance was in the poor category. Thus, the main factor in the implementation of school governance is the understanding of individual school members who must be precise with the education management standards, in what is this, the education management standards, and how they play a role in its implementation, as well as the impact of school governance, does not run according to education management standards.
\end{abstract}

Keywords: school governance, education management standards, public elementary schools.

Abstrak: Penelitian ini bertujuan untuk mengetahui tingkat pemahaman kepala sekolah, guru, dan komite sekolah terhadap implementasi standar pengelolaan pendidikan pada 
satuan pendidikan dasar dan menengah, khususnya di Sekolah Dasar Negeri. Penelitian ini menggunakan metode deskriptif kuantitatif. Data diperoleh dari Sekolah Dasar Negeri yang terakreditasi A dan B pada daerah perkotaan di delapan kabupaten/kota di Jawa Barat, dengan teknik sampling menggunakan purposive sampling. Data primer dalam penelitian ini adalah pengetahuan kepala sekolah, guru, dan komite sekolah terhadap standar pengelolaan pendidikan, sedangkan data skunder adalah dokumen instrumen implementasi standar pengelolaan pendidikan. Analisis data menggunakan statistik deskriptif. Hasil penelitian menunjukkan, pertama pemahaman kepala sekolah dan guru terhadap regulasi standar pengelolaan pendidikan tergolong cukup paham, sementara komite sekolah memiliki pemahaman terhadap regulasi standar pengelolaan pendidikan tergolong kurang. Kedua, berdasarkan hasil analisis data, kepala sekolah dan guru menganggap implementasi tata kelola sekolah tergolong cukup sesuai dengan standar pengelolaan pendidikan, sementara menurut komite sekolah implementasi tata kelola sekolah tergolong kurang. Dengan demikian, faktor utama implementasi tata kelola sekolah adalah pemahaman individu warga sekolah yang harus tepat terhadap standar pengelolaan pendidikan, hal apa saja yang termasuk dalam standar pengelolaan pendidikan, bagaimana perannya dalam implementasi, dan bagaimana dampaknya apabila tata kelola sekolah tidak berjalan sesuai dengan standar pengelolaan pendidikan.

Kata kunci: pengelolaan sekolah, standar pengelolaan pendidikan, sekolah dasar

\section{PENDAHULUAN}

Untuk mewujudkan cita-cita pendidikan yang diharapkan, pemerintah menentukan kriteria mutu pendidikan melalui Standar Nasional Pendidikan yang menjadi pedoman bagi pemerintah dan satuan pendidikan untuk mengelola dan mengembangkan pendidikan sesuai dengan tujuan pendidikan nasional. Standar Nasional Pendidikan (SNP) merupakan kriteria minimal tentang berbagai aspek yang relevan dalam pelaksanaan sistem pendidikan nasional yang harus dipenuhi oleh penyelenggara dan/atau satuan pendidikan di seluruh Indonesia. SNP berfungsi sebagai dasar dalam perencanaan, pelaksanaan, dan pengawasan pendidikan dalam rangka mewujudkan pendidikan nasional yang bermutu, dengan tujuan memberikan jaminan mutu pendidikan secara nasional (Sulfemi, 2020). SNP ditetapkan melalui Peraturan Pemerintah Nomor 19 Tahun 2005 dan direvisi melalui Peraturan Pemerintah Nomor 23 Tahun 2013 tentang Perubahan Atas Peraturan Pemerintah Nomor 19 Tahun 2005. Pada Peraturan Pemerintah Nomor 19 pasal 49 ayat (1), menyebutkan bahwa pengelolaan satuan pendidikan pada jenjang pendidikan dasar dan menengah menerapkan manajemen berbasis sekolah yang ditunjukkan dengan kemandirian, kemitraan, partisipasi, keterbukaan, dan akuntabilitas. Salah satu indikator dalam ketercapaian SNP adalah ketercapaian standar pengelolaan pendidikan. Standar pengelolaan pendidikan diatur melalui Peraturan Menteri Pendidikan Nasional Republik Indonesia Nomor 19 Tahun 2007 (Kementerian Pendidikan Nasional, 2007), tentang Standar Pengelolaan Pendidikan oleh Satuan Pendidikan Dasar dan Menengah, pasal 1 ayat (1) Setiap satuan pendidikan wajib memenuhi standar pengelolaan pendidikan yang berlaku secara nasional.

Manajemen pendidikan adalah serangkaian kegiatan yang dimulai dari perencanaan, pengorganisasian, penggerakan, sampai pengawasan yang dilakukan untuk mencapai tujuan secara efektif dan efisien. Sulfemi \& Yuliani (2019) berpendapat bahwa warga sekolah seperti kepala sekolah, guru, dan tenaga administrasi sekolah dalam melaksanakan tugas pengelolaan satuan pendidikan (sekolah) tidak terlepas dari fungsi mereka dalam melakukan 
Arsyad Djamalludin Palettei, Wahyu Bagja Sulfemi, Yusfitriadi, Tingkat Pemahaman Kepala Sekolah, Guru, Dan Komite Sekolah Terhadap Implementasi Standar Pengelolaan Pendidikan Di Sekolah Dasar

kegiatan manajemen yang terdiri dari perencanaan, pengorganisasian, penggerakan, dan pengawasan, sesuai dengan tugas dan kewenangan masing-masing. Palettei dan Sulfemi (2019) menyatakan bahwa manajemen sekolah yang berjalan dengan baik dapat meningkatkan mutu sekolah secara efisiensi dan efektif dengan menjalin kerja sama yang harmonis antara sekolah, masyarakat, dan pemerintah.

Ketercapaian standar pengelolaan pendidikan sesuai dengan SNP adalah salah satu indikator ketercapaian mutu pendidikan yang bermuara pada ketercapaian visi dan misi pendidikan secara nasional. Oleh karena itu, semua pihak harus berupaya untuk memenuhi standar pengelolaan pada tingkat satuan pendidikan. Masyarakat secara aktif dan proporsional bersama dengan pemangku kepentingan pendidikan dan pimpinan sekolah berkewajiban berupaya mencapai standar pengelolaan pendidikan, khususnya di sekolah dasar. Banyak hal yang sudah dilakukan pemerintah (Kementerian Pendidikan dan Kebudayaan, 2016), agar penyelenggaraan pendidikan nasional tercapai secara efisiens dan efektif, mulai dari kebijakan yang bersifat teknis sampai pada upaya peningkatan sumber daya, termasuk memperkuat infrastruktur pendidikan. Namun, dalam pelaksanaannya tingkat ketercapaian SNP masih rendah. Evaluasi perlu dilakukan mengingat implementasi kebijakan SNP sudah berjalan kurang lebih 15 tahun. Berdasarakan data indeks mutu sekolah dasar Direktorat Sekolah Dasar Kemendikbud 2018, menunjukkan tingkat ketercapaian SNP pada satuan pendidikan dasar masih bervariasi. Kualifikasi tingkat ketercapaian standar SNP dikategorikn dalam kualifikasi 1, 2, dan 3. Kualifikasi 1, 2 dan 3 tersebut belum sampai pada ketercapaian standar SNP secara keseluruhan. Sementara untuk klasifikasi nonSNP adalah data sekolah dasar yang belum ada yang memenuhi standar SNP, hal ini tergambar di beberapa propinsi (Tabel 1 ).

Khusus untuk standar pengelolaan pendidikan dengan beberapa subindikator di antaranya persoalan yang dialami sekolah dasar tergambar pada data distribusi 2018, tentang ketercapaian standar pengelolaan sekolah dasar (Tabel 2)

Berdasarkan data indeks mutu sekolah dasar di beberapa propinsi tersebut, menunjukkan bahwa subindikator pada standar mutu pengelolaan sekolah. Kategori M1, M2, M3 dan M4 adalah tingkat ketercapaian SNP sekolah

Tabel 1 Indeks Mutu Sekolah Dasar Beberapa Propinsi

\begin{tabular}{cccccc}
\hline Propinsi & Klasifikasi 1 & Klasifikasi 2 & Klasifikasi 3 & Non SNP & SD Jumlah \\
\hline Banten & 954 & 1465 & 611 & 568 & 5489 \\
Lampung & 451 & 1225 & 541 & 2463 & 4680 \\
Jateng & 12153 & 1417 & 2041 & 3445 & 19065 \\
Jatim & 9736 & 2658 & 2267 & 4719 & 19380 \\
\hline
\end{tabular}

Sumber: Direktorat Pembinaan Sekolah Dasar Kemendikbud RI. (2018).

Tabel 2 Distribusi Sub Indikator Standar Pengelolaan di SD

\begin{tabular}{llcccc}
\hline Subindikator & M1 & M2 & M3 & M4 & SNP \\
\hline Berjiwa wirausaha & 144.260 & 0 & 0 & 0 & 0 \\
Melakukan supervise & 144.260 & 0 & 0 & 0 & 0 \\
Berjiwa Kepemimpinan & 284 & 3959 & 19784 & 56191 & 42655 \\
Membangun kemitran & 174 & 3187 & 15067 & 78178 & 47650 \\
\hline
\end{tabular}

Sumber: Direktorat Pembinaan Sekolah Dasar Kemendikbud RI. (2018). 
berdasarkan rapor pada peta mutu pendidikan, mulai dari indeks mutu tingkat ketercapaian yang terendah dengan kategori M1, M2, M3 dan M4 sampai pada ketercapaian SNP yang menunjukkan bahwa sekolah sudah memenuhi SNP secara keseluruhan. Berdasarkan tabel 2, menunjukan tingkat ketercapaian SNP di sekolah dasar tergolong masih rendah. Hal ini diduga bukan karena standar nasional pendidikan yang kurang berkualitas, namun pemenuhan indikator implementasi SNP yang belum berjalan secara maksimal. Salah satunya adalah pernyataan visi misi sekolah yang belum dijadikan sebagai pedoman dalam merumuskan program-program sekolah. Merujuk pada hasil penelitian Sukaningtyas, Satori, dan Sa'ud (2017) bahwa visi dan misi sekolah merupakan tujuan akhir yang menjadi pedoman bagi aktivitas sekolah dan dapat difungsikan sebagai dasar kekuatan layanan bermutu ke peserta didik. Banyak sekolah menjadikan visi dan misi sekadar ada, tetapi tidak menjadi pedoman yang bermakna bagi penyelenggaraan pendidikan. Dari gambaran tersebut, dapat diasumsikan bahwa salah satu faktor yang memengaruhi rendahnya ketercapaian SNP, khususnya pada standar pengelolaan pendidikan adalah faktor warga sekolah yang belum memiliki pemahaman yang tepat mengenai apa itu tata kelola sekolah, peran dan implementasinya, dan dampak yang akan dirasakan apabila tidak terimplementasi dengan baik. Peran yang berbeda-beda dari warga sekolah dan masyarakat membawa pada adanya pembagian kerja berdasarkan karakteristik jabatannya di sekolah yang akan memengaruhi masing-masing individu untuk memahami dan melaksanakan tugasnya. Untuk mengoptimalkan peran warga sekolah dalam melaksanakan tugasnya, diperlukan koordinasi yang baik melalui kepemimpinan. Kepemimpinan di sekolah berperan dalam pemberdayaan pada guru, tenaga kependidikan, dan masyarakat yang terlibat di sekolah untuk diberi kewenangan dalam mengambil keputusan, sehingga mereka memiliki tanggung jawab yang besar (Raharjo, Yuliana, \& Yudha, 2018).

Implementasi standar pengelolaan pendidikan di sekolah dasar akan berjalan efektif melalui penerapan manajemen sekolah. Peran sekolah akan lebih besar dalam memberikan fleksibilitas dan mendorong partisipasi secara langsung warga sekolah (kepala sekolah, guru, siswa, tenaga administrasi) dan masyarakat (komite sekolah) untuk meningkatkan mutu sekolah sesuai dengan SNP (Sulfemi \& Mayasari, 2019). Berkaitan dengan hal tersebut, maka warga sekolah dituntut untuk memiliki pemahaman dan pengetahuan sesuai dengan peran dan tugasnya masing-masing dalam pelaksanaan tata kelola sekolah.

Pertama, kepala sekolah sebagai pemimpin utama di sekolah, dituntut untuk bertindak sesuai dengan kebutuhan dan perkembangan zaman. Kepala sekolah dapat didefinisikan sebagai seorang tenaga fungsional guru yang bertugas untuk memimpin sekolah yang menyelenggarakan proses belajar mengajar dan terjadinya interaksi antara guru yang memberi pelajaran dan siswa yang menerima pelajaran. Rumusan tersebut menunjukkan pentingnya peranan kepala sekolah dalam menggerakkan kehidupan sekolah untuk mencapai tujuan. Badarudin (2019) menyatakan bahwa kepala sekolah sebagai perencana menentukan sukses tidaknya suatu program yang telah direncanakan. Untuk itu, dibutuhkan kerja sama dan dukungan dari stakeholder, sehingga diharapkan semua pihak mempunyai rasa memiliki dan ikut berjanggung jawab dalam mensukseskan program tersebut. Kepemimpinan kepala sekolah merupakan faktor penting yang dapat mendorong terciptanya sekolah yang efektif, produktif, mandiri, dan akuntabel. Oleh karena itu, manajemen dan kepemimpinan kepala sekolah perlu lebih ditekankan dalam koordinasi, komunikasi, dan supervisi. Kelemahan dan hambatan pendidikan seringkali bersumber dari kurangnya koordinasi, komunikasi, dan 
Arsyad Djamalludin Palettei, Wahyu Bagja Sulfemi, Yusfitriadi, Tingkat Pemahaman Kepala Sekolah, Guru, Dan Komite Sekolah Terhadap Implementasi Standar Pengelolaan Pendidikan Di Sekolah Dasar

supervisi. Hal tersebut menyebabkan persepsi yang berbeda di antara komponen-komponen pelaksanaan di lapangan. Untuk itu, kepala sekolah harus energik, berkemauan keras, memiliki inisiatif, dan realistis untuk memajukan lembaga pendidikan dengan tetap mengedepankan prinsip koordinasi, komunikasi, dan supervisi dalam melaksanakan kepemimpinannya.

Kedua, bahwa ketercapaian standar pengelolaan pendidikan di sekolah tidak hanya kepala sekolah yang memiliki peran penting, tetapi juga guru. Guru merupakan salah satu komponen dalam sistem pendidikan yang memiliki peran yang sangat besar dalam pencapaian tujuan pendidikan. Peran guru bukan sekadar menyampaikan ilmu pengetahuan kepada peserta didik, melainkan juga berperan sebagai administrator pendidikan yang harus terampil dan handal. Guru memiliki tugas dan tanggung jawab yang kompleks terhadap pencapaian tujuan pendidikan. Guru tidak hanya dituntut untuk menguasai ilmu yang akan diajarkan dan memiliki seperangkat pengetahuan dan keterampilan teknis mengajar, tetapi juga dituntut untuk menampilkan kepribadian yang mampu menjadi teladan bagi siswa. Peran guru yang muncul secara intens selama ini dalam tata kelola sekolah adalah sebagai pelaksana. Kebanyakan guru masih menganggap tugasnya hanya mengajar, selesai mengajar mereka bebas dari tugas. Sehingga berbagai hal yang terkait dengan tata kelola sekolah dinilai menjadi tanggung jawab pimpinan sekolah. Dalam perspektif yang lebih jauh, guru harus mampu menunjukkan bahwa apa yang dilakukan oleh semua warga sekolah mengarah pada satu tujuan bersama. Peran guru dalam melaksanakan tata administrasi sekolah sangat penting, dan tidak bisa dipisahkan antara komponen yang satu dengan yang lain. Di samping itu, beberapa guru mendapat tugas tambahan dalam membantu kepala sekolah, seperti sebagai wakil kepala sekolah bidang kurikulum, sebagai wakil kepala sekolah bidang kesiswaan, sebagai wali kelas, sebagai guru bimbingan dan penyuluhan. Melihat tugas dan peran guru di sekolah sebagai unsur yang berhadapan dengan peserta didik, guru yang bermutu merupakan faktor yang menentukan mutu lembaga pendidikan, yang akan mewujudkan kemajuan bangsa. Untuk itu, Alawiyah (2018) menyatakan bahwa peningkatan kualitas guru merupakan faktor penting dalam mewujudkan SDM bangsa yang bermutu, yang siap, dan mampu bersaing dalam pergaulan dan pasar global saat ini.

Ketiga, partisipasi komite sekolah saat ini masih dipahami sebagai upaya mobilisasi untuk kepentingan pemerintah. Untuk itu, perlu ditumbuhkan adanya kemauan dan kemampuan kelompok masyarakat untuk berpartisipasi dalam pengembangan sekolah melalui komite sekolah. Peran yang paling menonjol pada komite sekolah adalah sebagai pendukung dan pemberi pertimbangan terhadap penyelenggaraan sekolah. Mengacu pada Permendikbud Nomor 75 tahun 2016 tentang Komite Sekolah, pasal 1 ayat (2) menyebutkan bahwa Komite Sekolah adalah lembaga mandiri yang beranggotakan orangtua/wali peserta didik, komunitas sekolah, serta tokoh masyarakat yang peduli pendidikan. Keterlibatan komite sekolah dapat dikategorikan besar dalam keberhasilan mengimplementasikan tata kelola sekolah. Hal ini disebabkan adanya kepercayaan dan kepentingan masyarakat terhadap sekolah. Sulfemi \& Kamalia (2020) mengemukakan bahwa hubungan sekolah dan masyarakat diharapkan mampu menumbuhkan kreativitas serta dinamika kedua belah pihak. Hubungan tersebut bersifat aktif dan dinamis. Prinsip transparansi yang dilakukan oleh keduanya akan mengarah pada profesionalisme pengelolaan kelembagaan yang senantiasa membawa ke arah perubahan yang inovatif dan akan berdampak pada peningkatan mutu kelembagaan secara menyeluruh.

Mencermati peran dan tugas kepala sekolah, guru, dan komite sekolah dalam implementasi tata kelola sekolah tersebut di atas, dapat 
disimpulkan bahwa kepala sekolah, guru, dan komite sekolah memiliki peran penting dalam mengimplementasikan tata kelola sekolah yang sesuai dengan standar pengelolaan. Oleh karena itu, mereka harus memahami dan mengetahui tentang kondisi sekolah, kebijakan yang berlaku, dan strategi implementasi yang efektif dan efesien. Dengan memahami ketiga aspek tersebut, kepala sekolah, guru, dan komite sekolah dianggap mampu mengimplementasikan tata kelola sekolah dengan indikator standar pengelolaan pendidikan melalui Instrumen Standar Pengelolaan, Supervisi, Monitoring, dan Evaluasi Kementerian Pendidikan Nasional Direktorat Jenderal Manajemen Pendidikan Dasar Dan Menengah tahun 2010. Instrumen tersebut meliputi pertama, memahami kondisi sekolah, yang terdiri dari rencana program, pelaksanaan rencana kerja, dan kegiatan sekolah. Kedua, kebijakan sekolah dan pemerintah tentang pengawasan, evaluasi, kepemimpinan, dan sistem informasi manajemen. Ketiga, strategi implementasi yang efektif, efisien dengan melibatkan peran serta komite sekolah serta masyarakat dalam mengelola pendidikan.

Tata kelola sekolah dasar adalah suatu rangkaian kegiatan sebagai bentuk implementasi dari suatu kebijakan. Evaluasi tata kelola sekolah dasar pada dasarnya merupakan kegiatan evaluasi terhadap implementasi dari suatu kebijakan. Untuk itu, perlu dilakukan evaluasi untuk mengetahui dan menentukan kebijakan strategis pencapaian SNP dan secara khusus standar pengelolaan pendidikan oleh satuan pendidikan dasar dan menengah, mengingat bahwa hakikat evaluasi adalah suatu proses yang sistematis dan berkelanjutan untuk menentukan kualitas berdasarkan pertimbangan dan kriteria tertentu dalam rangka mengambil keputusan.

Berdasarkan latar belakang dan kajian literatur di atas, dapat dirumuskan masalah dalam penelitian ini adalah sejauh mana tingkat pemahaman kepala sekolah, guru, komite sekolah dan implementasi tata kelola sekolah sesuai standar pengelolaan pendidikan. Dari rumusan masalah tersebut, tujuan penelitian ini adalah pertama, untuk mengetahui tingkat pemahaman kepala sekolah, guru, dan komite sekolah terhadap standar pengelolaan pendidikan di sekolah dasar. Kedua, mengetahui implementasi tata kelola sekolah sesuai standar pengelolaan pendidikan di sekolah dasar.

\section{METODE}

Penelitian ini merupakan kajian dari Lembaga Studi Visi Nusantara (LS-Vinus) tahun 2019 dengan topik evaluasi tata kelola Sekolah Dasar Negeri. Lokus penelitian dilaksanakan di jawab Barat, pada bulan Juli s.d. Oktober 2019. Penelitian ini menggunakan metode deskriptif kuantitatif. Data penelitian diperoleh dari Sekolah Dasar Negeri di delapan kabupaten/Kota di Jawa Barat meliputi; Kabupaten Bogor, Kota Bogor, Kota Depok, Kota Bekasi, Kabupaten Bekasi, Kabupaten Karawang, Kabupaten Cianjur, dan Kabupaten Sukabumi. Teknik sampling menggunakan purposive sampling, dengan langkah-langkah, yaitu 1) menetapkan kecamatan pada daerah perkotaan atau kecamatan ibu kota kabupaten/kota, 2) menentukan tiga sekolah dasar negeri di setiap kecamatan ibu kota kabupaten/kota, dengan akreditasi $A$ atau $B, 3$ ) menentukan responden setiap sekolah dasar negeri terdiri dari satu kepala sekolah, satu guru, dan satu komite sekolah. Dengan demikian, diperoleh 24 sekolah dasar negeri dengan jumlah sampel sebanyak 216 responden. Teknik pengambilan data menggunakan instrumen angket dengan skala likert. Sugiyono (2013) Skala Likert digunakan untuk mengukur sikap, pendapat responden tentang fenomena sosial, dengan alternatif jawaban yaitu dengan memberikan skor pada masing-masing pertanyaan/pernyataan, seperti Tabel 3. 
Arsyad Djamalludin Palettei, Wahyu Bagja Sulfemi, Yusfitriadi, Tingkat Pemahaman Kepala Sekolah, Guru, Dan Komite Sekolah Terhadap Implementasi Standar Pengelolaan Pendidikan Di Sekolah Dasar

Tabel 3 Alternatif Jawaban Dengan Skala Likert

\begin{tabular}{lc}
\hline Alternatif Jawaban & Bobot nilai \\
\hline Sangat paham/sesuai & 5 \\
Paham/sesuai & 4 \\
Cukup paham/sesuai & 3 \\
Kurang paham/sesuai & 2 \\
Kurang paham/sesuai & 1 \\
Tidak paham/sesuai & 0 \\
\hline
\end{tabular}

Sumber: Sugiyono (2013).

Data dalam penelitian ini terdiri dari data utama atau primer dan data kedua atau skunder. Data primer dalam penelitian ini adalah pengetahuan atau pendapat kepala sekolah, guru, dan komite sekolah terhadap standar pengelolaan pendidikan. Sedangkan data skunder dalam penelitian ini diperoleh dari pedoman instrumen implementasi tata kelola sekolah yang sesuai standar pengelolaan pendidikan. Pemahaman warga sekolah terhadap tata kelola sekolah adalah kemampuan untuk memahami kondisi sekolah dan kebijakan regulasi standar pengelolaan pendidikan, dengan indikator yaitu; (1) perencanaan program dan pelaksanaan rencana kerja dan kegiatan, (2) pengawasan dan evaluasi, (3) kepemimpinan sekolah, (4) sistem informasi manajemen sekolah, (5) sekolah membangun kemitraan dan melibatkan peran serta komite sekolah. Sementara implementasi tata kelola sekolah adalah suatu rangkaian kegiatan sebagai bentuk implementasi dari suatu kebijakan pendidiikan nasional yang disusun secara sistematis dan terperinci, sebagai panduan dalam tata kelola pendidikan oleh satuan pendidikan dasar, dengan indikator yaitu: (1) dokumen perencanaan program yang mengacu pada rumusan dan penetapan visi, misi, dan tujuan sekolah, dokumen pedoman rencana kerja, dan pengelolaan sekolah, (2) program pelaksanaan, sosialisasi, dan pengawasan serta evaluasi diri, (3) kepemimpinan kepala sekolah, (4) pengelolaan informasi manajemen sekolah, (5) perencanaan yang melibatkan komite sekolah. Analisis data menggunakan statistik deskriptif yaitu menghimpun, menyusun, mengolah, menyajikan, dan menganalisis data angka agar dapat memberikan gambaran yang teratur, ringkas, dan jelas mengenai suatu gejala atau peristiwa (Anas, 2012). Ada dua tahapan dalam melakukan analisis dalam kegiatan penelitan ini. Data dianalisis terlebih dahulu dengan metode kuantitatif, kemudian dianalisis dengan metode kualitatif pendekatan studi kasus yaitu untuk mengkaji suatu kasus atau fenomena tertentu yang ada dalam masyarakat yang dilakukan secara mendalam untuk mempelajari latar belakang, keadaan, dan interiaksi yang terjadi pada suatu kesatuan sistem yang bisa berupa suatu program, kegiatan, peristiwa, atau sekelompok individu yang ada pada keadaan atau kondisi tertentu (Yusuf, 2013). Dalam penelitian ini yaitu mendeskripsikan tingkat pemahaman dan implementasi tata kelola sekolah dasar sesuai dengan standar pengeIolaan pendidikan menurut para responden.

\section{HASIL DAN PEMBAHASAN Hasil}

Tujuan pertama pada penelitian ini adalah untuk mengetahui tingkat pemahaman responden terhadap standar pengelolaan pendidikan di sekolah dasar. Data hasil penelitian menunjukkan bahwa tingkat pemahaman para responden dengan sebaran hasil angket berdasarkan indikator yaitu, kepala sekolah dan guru memiliki pemahaman rata-rata cukup, sementara komite sekolah memiliki pemahaman dengan rata-rata sangat kurang atau kurang paham. Gambar 1 adalah grafik hasil sebaran.

Berdasarkan Gambar 1, hasil dari 5 butir angket pada masing-masing indikator tentang tingkat pemahaman responden terhadap standar pengelolaan pendidikan kategori sangat paham, paham, cukup paham, kurang paham, dan tidak paham dengan kriteria interpretasi skor berdasarkan intervalnya, dapat dilihat pada Tabel 4. 


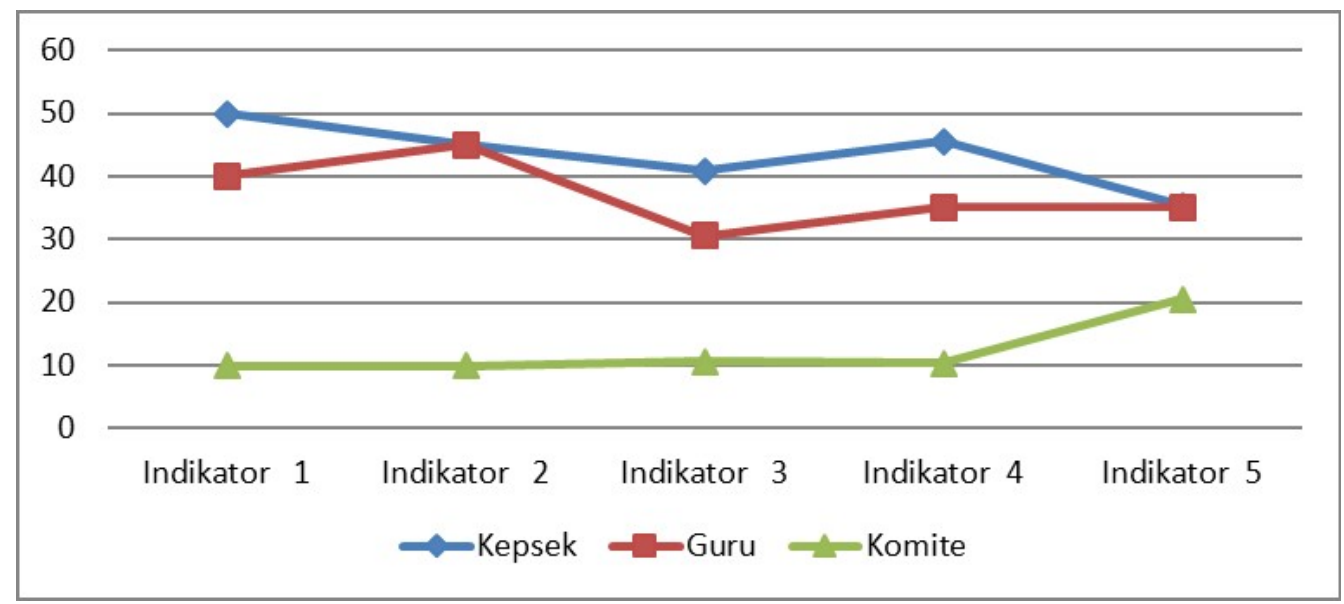

Gambar 1. Tingkat Pemahaman Responden terhadap Tata kelola SD

Tabel 4 Kriteria Intepretasi Skor

\begin{tabular}{ll}
\hline Nilai Interval & Interpretasi \\
\hline Angka $0 \%-19,99 \%$ & $\begin{array}{c}\text { Sangat kurang } \\
\text { paham } \\
\text { Kurang paham }\end{array}$ \\
Angka $20 \%-39,99 \%$ & Cukup paham \\
Angka $40 \%-59,99 \%$ & Sangat paham \\
Angka $60 \%-79,99 \%$ & Sangat paham \\
Angka $80 \%-100,99 \%$ &
\end{tabular}

Sumber: Sugiyono (2013)

Adapun hasil sebaran angket sebagai berikut. Indikator pertama yaitu perencanaan program, pelaksanaan rencana kerja, dan kegiatan dengan buitr indikator; butir angket 1 visi misi sekolah dan tujuan sekolah, butir angket 2 rencana kerja sekolah, pedoman pengelolaan sekolah, butir angket 3 pengelolaan sekolah dalam kurikulum, kalender pendidikan/ akademik, struktur organisasi sekolah dan pembagian tugas di antara guru, butir angket 4 pelaksanaan kegiatan bidang pengelolaan pendayagunaan pendidik dan tenaga kependidikan, dan butir angket 5 keterlibatan masyarakat pendukung dan membangun kemitraan dengan lembaga lain yang relevan. Hasil tersebut menunjukkan tingkat pemahaman kepala sekolah dan guru berdasarkan kriteria interpretasi skor dengan kategori cukup paham, yaitu rata-rata $40 \%$. Sementara komite sekolah memiliki pemahaman di bawah $20 \%$, pada kategori sangat kurang atau tidak paham. Hasil ini juga menunjukkan rata-rata yang sudah cukup dipahami oleh responden adalah butir angket 1 , 3, dan 4, sementara yang tidak dipahami adalah butir angket nomor 2 dan 5 .

Indikator kedua yaitu pengawasan dan evaluasi, dengan butir indikator yaitu; butir angket 1 program sekolah dalam pengawasan secara obyektif, bertanggung jawab dan berkelanjutan, butir angket 2 evaluasi diri terhadap kinerja yang dilakukan sekolah, butir angket 3 evaluasi dan pengembangan kurikulum di sekolah, butir angket 4 evaluasi pendayagunaan pendidik dan tenaga kependidikan dengan mengacu pada standar pendidik dan tenaga kependidikan, dan butir angket 5 proses evaluasi dan akreditasi yang dilakukan sekolah. Data menunjukkan bahwa kepala sekolah dan guru memiliki pemahaman rata-rata $40 \%$, masuk kategori cukup paham. Komite sekolah memiliki pemahaman di bawah 20\%, masuk pada kategori sangat kurang paham. Data hasil penelitian menunjukkan bahwa aspek yang sudah cukup dipahami responden pada indikator ini adalah butir angket 1, 3, dan 5, sementara yang kurang dan tidak dipahami adalah butir angket 2 dan 4.

Indikator ketiga yaitu kepemimpinan sekolah, dengan butir indikator yaitu; butir angket 1 penjabaran visi ke yang dilakukan 
kepala sekolah, butir angket 2 keterlibatan guru dalam pengambilan keputusan penting sekolah, butir angket 3 penerapan jiwa kepemimpinan, butir angket 4 jiwa kewirausahaan dalam kepemimpinan di sekolah, dan butir angket 5 pendelegasian sebagian tugas dan kewenangan kepada wakil kepala sekolah sesuai dengan bidangnya. Data menunjukkan bahwa kepala sekolah memiliki pemahaman rata-rata 40\%, dengan kategori cukup. Guru memiliki pemahaman di bawah 40\%, dengan kategori kurang paham, sementara komite sekolah dengan pemahaman di bawah $20 \%$ dengan kategori sangat kurang. Data angket yang sudah cukup dipahami oleh responden adalah butir nomor 2 dan 5 , sementara angket yang kurang dan belum dipahami adalah butir angket 1, 3 dan 4 .

Indikator keempat yaitu sistem informasi manajemen sekolah, dengan butir indikator yaitu; butir angket 1 pengelolaan sistem informasi manajemen, butir angket 2 fasilitas informasi yang efesien, efektif dan mudah diakses di sekolah, butir angket 3 penugasan kepada seorang guru atau tenaga kependidikan untuk melayani permintaan informasi, butir angket 4 laporan data informasi sekolah yang telah terdokumentasikan dan butir angket 5 komunikasi antar warga sekolah di lingkungan sekolah dilaksanakan secara efisien dan efektif. Berdasarkan data hasil sebaran butir angket menunjukkan tingkat pemahaman kepala sekolah berada $40 \%$ dengan kategori cukup. Untuk guru rata-rata di atas 30\% dengan kategori kurang, sementara kom ite sekolah dengan rata-rata di bawah 20\%, masuk pada kategori sangat kurang. Adapun aspek yang cukup dipahami oleh responden pada indikator ini adalah butir angket 1 dan 5, sementara tingkat pemahaman pada kategori kurang dan belum dipahami adalah butir angket 2, 3, dan 4 .

Indikator kelima yaitu sekolah membangun kemitraan dan melibatkan peran serta komite sekolah, dengan butir indikator yaitu butir angket 1 keterlibatan warga dan masyarakat pendukung sekolah dalam mengelola pendidikan, butir angket 2 sekolah menjalin kemitraan dengan lembaga lain yang relevan, butir angket 3 membangun kemitraan dan melibatkan peran serta masyarakat dalam pengelolaan sekolah, butir angket 4 kemitraan sekolah dilakukan dengan lembaga pemerintah atau non pemerintah, dan butir angket 5 kepala sekolah bersosialisasi dengan baik dalam memimpin sekolah dengan warga sekolah. Data hasil sebaran 5 butir angket menunjukkan bahwa kepala sekolah, guru, dan komite sekolah memiliki pemahaman yang sama yaitu dengan kategori kurang. Data ini memperlihatkan bahwa kepala sekolah, guru, dan komite sekolah memiliki tingkat pemahaman yang kurang. Adapun urutan tingkat yang kurang dipahami responden yaitu mulai dari butir angket 3, 4, 5, 2, dan 1. Gambar 2 adalah grafik hasil sebaran butir angket per indikator.

Berdasarkan hasil analisis data di atas, tingkat pemahaman kepala sekolah, guru, dan komite sekolah yang paling kuat adalah pada indikator visi, misi, dan tujuan sekolah. Penyusunan dan pelaksanaan serta rencana kerja sekolah adalah indikator yang paling kurang dipahami kepala sekolah, guru, dan komite sekolah dari indikator kepemimpinan kepala sekolah.

Tujuan penelitian kedua adalah untuk mengetahui implementasi tata kelola sekolah sesuai standar pengelolaan pendidikan. Berdasarkan hasil dari 5 butir angket dari masingmasing indikator tergambar pada hasil data yang menunjukkan bahwa para responden memiliki perbedaan penilaian terhadap implementasi tata kelola sekolah sesuai standar pengelolaan pendidikan dengan melihat kesesuaian dokumen, yaitu mulai dari sangat sesuai, sesuai, cukup sesuai, kurang sesuai, dan sangat kurang sesuai dengan kriteria interpretasi skor berdasarkan intervalnya (Tabel 5). 


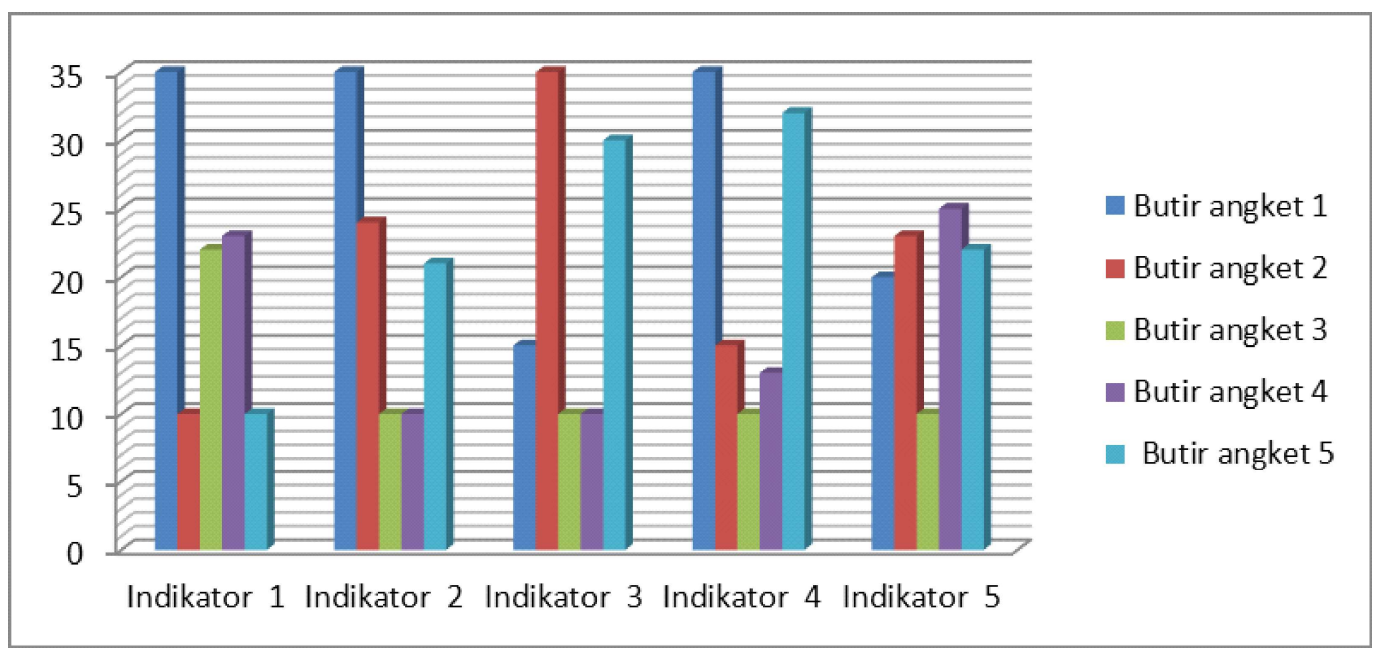

Gambar 2. Sebaran Butir Angket Per Indikator

Tingkat Pemahaman Pada Tata Kelola Sekolah

Tabel 5 Kriteria Intepretasi Skor

\begin{tabular}{ll}
\hline Nilai Interval & Interpretasi \\
\hline Angka $0 \%-19,99 \%$ & $\begin{array}{l}\text { Sangat kurang } \\
\text { paham/sesuai }\end{array}$ \\
Angka $20 \%-39,99 \%$ & Kurang paham/sesuai \\
Angka $40 \%-59,99 \%$ & Cukup paham/sesuai \\
Angka $60 \%-79,99 \%$ & Paham/sesuai \\
Angka $80 \%-100,99 \%$ & Sangat paham/sesuai
\end{tabular}

Sumber: Sugiyono (2012)

Berdasarkan hasil penelitian dan mengacu pada kriteria interpretasi skor, hasil sebaran angket sebagai dapat dilihat pada Gambar 3.
Berdasarkan Gambar 3, tujuan kedua penelitian untuk indikator pertama yaitu, perencanaan program, pelaksanaan rencana kerja, dan kegiatan dengan butir indikator; butir angket 1 sekolah dikelola berdasarkan dengan visi, misi, dan tujuan, butir angket 2 kegiatan sekolah dilaksanakan berdasarkan rencana kerja tahunan, butir angket 3 sekolah menyusun pedoman pengelolaan sekolah kurikulum butir angket 4 kegiatan sekolah dilaksanakan berdasarkan rencana kerja tahunan, dan butir angket 5 sekolah melibatkan pemangku kepentingan dalam menyusun rencana

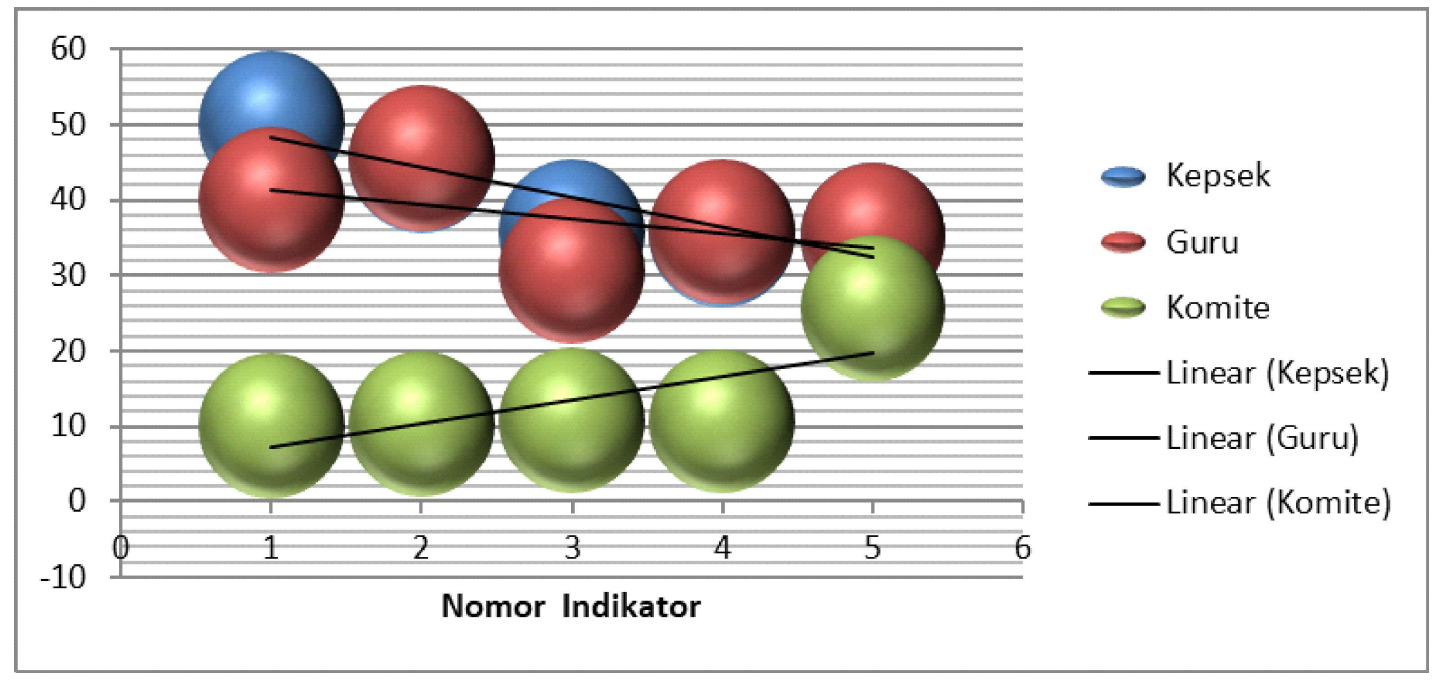

Gambar 3. Implementasi Tata Kelola SD Menurut Responden 
Arsyad Djamalludin Palettei, Wahyu Bagja Sulfemi, Yusfitriadi, Tingkat Pemahaman Kepala Sekolah, Guru, Dan Komite Sekolah Terhadap Implementasi Standar Pengelolaan Pendidikan Di Sekolah Dasar

pengelolaan sekolah. Data menunjukkan tingkat penilaian yang berbeda pada implementasi tata kelola sekolah. Dengan hasil sebaran 5 butir angket menunjukkan bahwa kepala sekolah dan guru memiliki penilaian rata-rata $40 \%$, dengan kategori cukup. Komite sekolah dengan penilaian rata-rata di bawah $20 \%$, kategori sangat kurang. Hasil ini menunjukkan rata-rata yang sudah cukup terimplementasi oleh responden adalah pada butir angket 3, 1, dan 2, sementara yang belum adalah butir angket 4 dan 5 .

Indikator kedua yaitu pengawasan dan evaluasi, dengan butir indikator, yaitu; butir angket 1 sekolah menyusun program pengawasan secara obyektif, bertanggung jawab, dan berkelanjutan, butir angket 2 sekolah melakukan evaluasi diri terhadap kinerja sekolah, butir angket 3 sekolah melaksanakan proses evaluasi dan pengembangan kurikulum, butir angket 4 sekolah melakukan evaluasi pendayagunaan pendidik dan tenaga kependidikan secara komprehensif, dan butir angket 5 sekolah menyiapkan bahan-bahan yang diperlukan untuk meningkatkan akreditasi sesuai dengan peraturan perundang-undangan yang berlaku. Gambar 2 diatas menunjukkan bahwa hasil sebaran 5 butir angket untuk kepala sekolah menganggap sudah mengimplementasikan tata kelola dengan nilai rata-rata $40 \%$ dengan kategori cukup. Untuk guru menilai dengan ratarata 35\%, kategori kurang. Sementara komite sekolah menganggap sangat kurang dengan nilai rata-rata di bawah $20 \%$. Hasil ini juga mengungkapkan bahwa rata-rata yang sudah dianggap cukup terimplementasi adalah pada butir angket 5 dan 3, sementara yang belum adalah butir angket nomor 2, 4 dan 1 .

Indikator ketiga yaitu kepemimpinan sekolah, dengan butir indikator, yaitu; butir angket 1 kepala sekolah menjabarkan visi ke dalam misi target mutu, butir angket 2 melibatkan guru, komite sekolah dalam pengambilan keputusan penting sekolah, butir angket 3 kepala sekolah menerapkan jiwa kepemimpinan, butir angket 4 kepala sekolah memperlihatkan jiwa kewirausahaannya dalam memimpin sekolah, dan butir angket 5 kepala sekolah mendelegasikan sebagian tugas dan kewenangan kepada wakil kepala sekolah sesuai dengan bidangnya. Data hasil sebaran 5 butir angket pada Gambar 2 indikator ketiga menunjukkan bahwa kepala sekolah dan guru memiliki penilaian rata-rata di bawah $40 \%$ dengan kategori kurang, sementara menurut komite sekolah memiliki penilaian rata-rata di bawah 20\%, dengan kategori sangat kurang. Hasil ini juga menunjukkan rata-rata yang dianggap sudah cukup terimplementasi oleh responden adalah pada butir angket 1 dan 5, sementara yang belum adalah butir angket 2,4 dan 3.

Indikator keempat yaitu sistem informasi manajemen, dengan butir indikator, yaitu; butir angket 1 sekolah mengelola sistem informasi manajemen yang memadai, butir angket 2 sekolah menyediakan fasilitas informasi yang efesien, efektif dan mudah diakses, butir angket 3 sekolah menugaskan seorang guru atau tenaga kependidikan untuk melayani permintaan informasi, butir angket 4 melaporkan data informasi sekolah yang telah terdokumentasikan, dan butir angket 5 komunikasi antar warga sekolah di lingkungan sekolah dilaksanakan secara efisien dan efektif. Hasil dari 5 sebaran butir menunjukkan bahwa kepala sekolah dan guru menganggap pihak sekolah masih kurang dalam mengimplementasikan tata kelola sekolah, dengan penilaian rata-rata di bawah $40 \%$, sementara komite sekolah rata-rata penialaian di bawah 20\%, dengan kategori sangat kurang. Data hasil sebaran butir angket pada indikator ini menunjukkan rata-rata yang sudah dianggap cukup terimplementasi oleh responden adalah pada butir angket nomor 5 dan 1, sementara yang belum adalah butir angket nomor 2, 4 dan 3.

Kelima, sekolah membangun kemitraan dan melibatkan peran serta komite sekolah, dengan 
butir indikator, yaitu; butir angket 1 sekolah melibatkan warga dan masyarakat pendukung sekolah dalam mengelola pendidikan, butir angket 2 sekolah menjalin kemitraan dengan wali murid dalam pengelolaan sekolah, butir angket 3 sekolah membangun kemitraan dan melibatkan peran serta masyarakat dalam pengelolaan sekolah, butir angket 4 kemitraan sekolah dilakukan dengan lembaga pemerintah, dan butir angket 5 kepala sekolah bersosialisasi dengan baik dalam memimpin sekolah dengan warga sekolah. Hasil sebaran 5 butir angket juga menunjukkan bahwa baik kepala sekolah, guru, dan komite sekolah memiliki penilaian yang sama terhadap implementasi tata kelola sekolah yaitu rata-rata penilaian di bawah $40 \%$ dan di atas $25 \%$, masuk kategori kurang. Komite sekolah memiliki penilaian yang lebih baik pada indikator ini yaitu kurang dibanding dengan indikator pada 1, 2, 3 dan 4 yaitu sangat kurang. Hasil data tersebut juga menunjukkan semua butir angket dianggap masih kurang dalam impelementasinya. Gambar 4 adalah grafik hasil sebaran butir angket per indikator.

Berdasarkan hasil analisis data di atas, indikator yang dianggap paling terimplementasi menurut kepala sekolah, guru, dan komite sekolah adalah sekolah merumuskan dan menetapkan visi lembaga disertai dengan rumusan indikator-indikator visi, misi dan tujuan sekolah, penyusunan dan pelaksanaan dan rencana kerja sekolah. Indikator yang paling kurang terimplementasi adalah pada indikator kepemimpinan kepala sekolah.

\section{Pembahasan}

Berdasarkan data hasil penelitian, tingkat pemahaman responden terhadap standar pengelolaan pendidikan secara umum pada kategori cukup paham. Hal ini terlihat pada butir angket yang rata-rata cukup dipahami oleh responden yaitu (1) perumusan dan penetapan visi, misi, dan tujuan sekolah dengan subindikator perumusan dan penetapan visi lembaga yang sesuai dengan perkembangan dan tantangan di masyarakat, perumusan dan penetapan misi sekolah yang sesuai dengan visi lembaga bersama warga sekolah, perumusan dan penetapan tujuan sekolah; (2) pelaksanaan Kerja Sekolah (RKS) atau rencana kerja tahunan; (3) program pelaksanaan pengawasan dan evaluasi diri; dan (4) perencanaan yang melibatkan komite sekolah. Sementara indikator yang kurang dipahami oleh responden yaitu (1) aspek kepemimpinan di sekolah dengan subindikator standar pengelolaan pendidikan yaitu berjiwa kepemimpinan dengan memberi keteladanan, contoh konkrit dan menumbuhkan jiwa kewirausahaan pada warga sekolah; dan (2) pengelolaan informasi manajemen sekolah dengan subindikator standar pengelolaan pendidikan pada pengelolaan sistem informasi

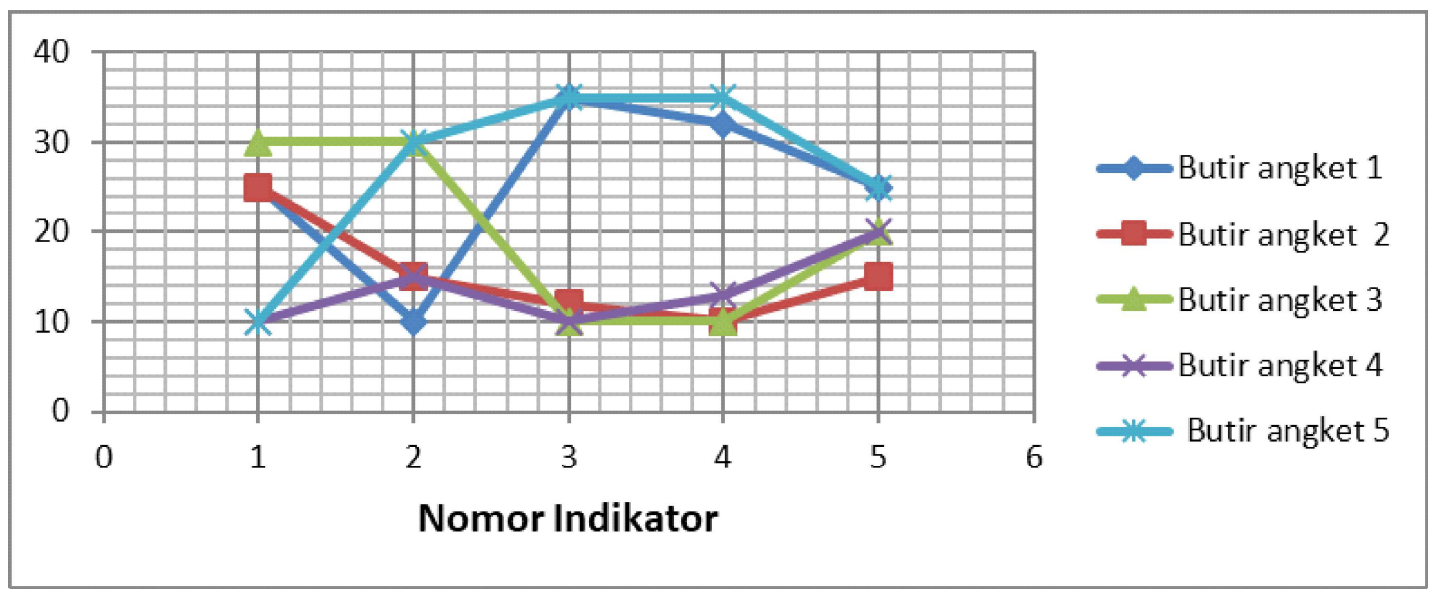

Gambar 4. Hasil Sebaran Butir Angket Per Indikator Implementasi Tata Kelola Sekolah 
Arsyad Djamalludin Palettei, Wahyu Bagja Sulfemi, Yusfitriadi, Tingkat Pemahaman Kepala Sekolah, Guru, Dan Komite Sekolah Terhadap Implementasi Standar Pengelolaan Pendidikan Di Sekolah Dasar

manajemen sekolah dalam bentuk penyebarluasan dan penerimaan informasi berbasis teknologi informasi untuk mendukung administrasi pendidikan seperti foto, leaflet, booklet, dan buletin. Dengan demikian, pemahaman yang cukup pada beberapa aspek indikator dalam standar pengelolaan pendidikan di sekolah berimplikasi pada terimplementasinya beberapa subindikator tata kelola sekolah dengan kategori cukup baik. Namun demikian, tingkat pemahaman komite sekolah terhadap standar pengelolaan pendidikan yang tergolong kurang paham, berpengaruh terhadap implementasi tata kelola sekolah yang belum berjalan secara menyeluruh sesuai standar pengelolaan pendidikan.

Aspek yang dianggap kurang dipahami, terutama oleh komite sekolah, berpengaruh pada tingkat implementasi tata kelola sekolah. Hal ini sejalan dengan data pencapaian standar pengelolaan sekolah dasar yang juga menunjukkan hal yang sama bahwa pada subindikator kepala sekolah berkinerja baik dengan pencapaian rata-rata pada M1 dan M2. Subindikator kepala sekolah berjiwa kewirausahaan juga ketercapaian SNP masih rendah, berada pada rata-rata M1. Subindikator standar pengelolaan sistem informasi manajemen sekolah dengan pencapaian SNP yang juga terbilang rendah yaitu rata-rata pada posisi M2.

Penyelenggaraan pendidikan di sekolah dasar yang bermutu tidak terlepas dari ukuran standar yang akan dicapai. Hasil penelitian Yuliana \& Raharjo (2019) mengungkapkan bahwa kedelapan Standar Nasional Pendidikan, terdapat standar yang memiliki kontribusi secara signifikan yaitu standar isi, kompetensi lulusan, pendidik dan tenaga kependidikan, sarana \& prasarana, serta pengelolaan. Artinya, ketercapaian standar pengelolaan pendidikan menjadi salah satu indikator mutu sekolah. Yuliana \& Raharjo (2019) juga menyatakan tentang ketercapaian standar nasional pendidikan di sekolah menengah atas, bahwa kendala standar pengelolaan yang dihadapi sebagian sekolah adalah belum memiliki sistem informasi yang terbaik sesuai dengan perkembangan teknologi dan keterbatasan SDM yang ada. Untuk itu, pengelolaan sekolah disarankan kebijakan harus fokus pada peningkatan kemampuan manajerial kepala sekolah yang mencakup sumber daya maupun kewirausahaan.

Sementara untuk peran komite sekolah, hasil penelitian menunjukkan bahwa pemahaman komite sekolah terhadap tata kelola sekolah sesuai standar pengelolaan pendidikan terbilang cukup paham. Hasil ini berpengaruh pada peran komite sekolah dalam melaksanakan fungsinya sebagai bagian penting dari pengelolaan sekolah. Peran komite sekolah juga penting untuk mendukung kelancaran kegiatan dan programprogram sekolah, seperti ketercapaian hasil pembelajaran. Arsyad \& Salahudin (2018) mengungkapkan bahwa untuk mencapai hasil pembelajaran yang baik, peran semua unsur sekolah, mulai dari kepala sekolah sampai orang tua siswa dan masyarakat sangat penting dalam mendukung keberhasilan pencapaian tujuan pembelajaran. Priatna (2018) menyatakan bahwa besarnya keterlibatan masyarakat dan pemangku kepentingan dalam program pengembangan mutu sekolah telah cukup besar yang menempatkan pemangku kepentingan dan masyarakat sebagai bagian dalam proses pendidikan yang berlangsung. Terkait dengan keterlibatan pihak sekolah dalam implementasi tata kelola sekolah melalui kepemimpinan di sekolah. Mistrianingsih, Imron, \& Nurabadi (2016) mengungkapkan bahwa faktor pendukung peran kepala sekolah dalam implementasi tata kelola sekolah adalah adanya dorongan untuk bekerja dan mengabdi kepada sekolah, motivasi belajar siswa, terjalinnya kekeluargaan di sekolah, dan peran serta masyarakat. Keterlibatan masyarakat terhadap penyelenggaraan sekolah melalui komite sekolah sangat penting karena dengan keterlibatannya berarti ada 
kepercayaan dan kepentingan yang dirasakan masyarakat terhadap sekolah, sehingga tergerak untuk memberikan dukungannya kepada sekolah.

Berdasarkan pembahasan dan analisis hasil penelitian di atas, tingkat pemahaman responden terhadap tata kelola sekolah secara umum pada kategori cukup paham. Implikasi tata kelola sekolah juga terimplementasi pada kategori cukup. Hal ini terlihat dari tidak lengkapnya sebagian dokumen pengelolaan pendidikan di sekolah yang menjadi acuan dalam melaksanakan tata kelola sekolah sesuai standar pengelolaan pendidikan. Untuk itu, pemahaman yang baik dari kepala sekolah, guru, dan komite sekolah sesuai dengan peran dan tugasnya masing-masing merupakan faktor penting dan sebagai dasar utama terlaksananya tata kelola sekolah. Tanpa memiliki pemahaman yang baik terhadap kondisi sekolah, kebijakan atau regulasi yang berlaku, serta strategi implementasi yang efektif dan efesien tentu kepala sekolah, guru, dan komite sekolah tidak akan dapat mengimplementasikan tata kelola sekolah sesuai Permendikbud Nomor 19 tahun 2007 tentang Standar Pengelolaan Pendidikan oleh Satuan Pendidikan Dasar dan Menengah. Dengan demikian, faktor yang menjadi hambatan dalam implementasi tata kelola sekolah adalah faktor individu warga sekolah yang belum memiliki pola pikir yang tepat mengenai standar pengelolaan pendidikan, bagaimana peran mereka dalam implementasi tata kelola sekolah, dan bagaimana dampak yang akan dirasakan oleh sekolah apabila tata kelola sekolah tidak berjalan sesuai standar pengelolaan pendidikan.

Mengacu pada kebijakan pemerintah tentang standar pegelolaan pendidikan untuk memenuhi ketercapaian SNP, kepala sekolah, guru, dan komite sekolah harus memiliki pemahaman yang baik terhadap regulasi standar pengelolaan pendidikan sehingga tata kelola sekolah berjalan sesuai dengan pedoman instrumen pengelolaan pendidikan di sekolah.
Hal ini sejalan dengan kebijakan Kementerian Pendidikan dan Kebudayaan tentang Merdeka Belajar. Program merdeka belajar merupakan bentuk penyesuaian kebijakan untuk memberikan kemerdekaan pada sekolah dalam menginterpretasi kompetensi dasar kurikulum dan manajemen pengelolaan sekolah sesuai tuntutan perkembangan ilmu pengetahuan dan teknologi, seperti penguatan kurikulum dengan konsep yang menunjukkan kemampuan minimum dalam hal literasi dan numerik serta konsep pembelajaran yang menekankan pada pengembangan kemampuan kognitif peserta didik agar bisa membuat keputusan yang bijak dalam penyelesaian masalah. Kebijakan konsep merdeka belajar melalui penguatan kurikulum sesuai standar pendidikan 4.0. Hal ini untuk memperkuat kebijakan standar pengelolaan pendidikan di satuan pendidikan dasar dengan penguatan sumber daya manusia sekolah (SDM) yang unggul dan kompetitif agar dapat mendukung proses pendidikan ke depan dengan tantangan baru, yakni pengelolaan kurikulum sesuai standar pendidikan era 4.0, konsep pembelajaran berbasis digital, serta guru profesional dan berkualitas. Untuk itu, penguatan SDM sekolah khususnya di sekolah dasar diharapkan mampu menjawab tantangan dalam penyelenggaraan proses pendidikan sesuai standar pengelolaan pendidikan dengan manajemen modern berbasis sekolah dan berbasis jaringan internet.

\section{SIMPULAN DAN SARAN \\ Simpulan}

Hasil penelitian ini menunjukkan, pertama, ada perbedaan tingkat pemahaman responden mengenai tata Kelola sekolah, yaitu kepala sekolah dan guru memiliki pemahaman secara umum cukup, sementara komite sekolah memiliki pemahaman yang kurang. Pemahaman kepala sekolah dan guru yang cukup terlihat dari indikator-indikator dalam standar pengelolaan pendidikan dengan urutan tingkat pemahaman 
mulai dari indikator pertama yaitu perencanaan program dan pelaksanaan rencana kerja dan kegiatan; indikator kedua yang terdiri atas pengawasan dan evaluasi; indikator kelima yakni sekolah yang melibatkan peran serta komite sekolah; indikator keempat berkaitan dengan sistem informasi manajemen sekolah; dan indikator ketiga yang menyoroti kepemimpinan sekolah. Kedua, pada implementasi tata kelola sekolah, kepala sekolah dan guru menganggap bahwa pihak sekolah secara umum cukup dalam mengimplementasikan tata kelola sesuai standar pengelolaan pendidikan, sementara komite sekolah menganggap pihak sekolah masih kurang dalam menjalankan tata kelola sekolah yang sesuai standar pengelolaan pendidikan yang terlihat adalah indikator kepemimpinan kepala sekolah dan pengelolaan informasi manajemen sekolah.

\section{Saran}

Dalam rangka ketercapaian standar pengelolaan pendidikan di sekolah dasar, pihak sekolah perlu melaksanakan kegiatan untuk meningkatkan pemahaman warga sekolah dan komite sekolah terhadap regulasi standar pengelolaan pendidikan melalui kegiatan pelatihan yang terencana. Disamping itu, dinas pendidikan kabupaten/kota perlu memperkuat aspek kepemimpinan di sekolah dengan menumbuhkan semangat jiwa kepemimpinan, jiwa wirausaha, dan memperkuat sistem informasi manajemen sekolah berbasis digital melalui pelatihan penguatan kompetensi kepala sekolah secara berkala dan terencana. Sementara itu, untuk mewujudkan manajemen tata kelola sekolah sesuai dengan standar pengelolaan pendidikan di satuan pendidikan dasar yang sejalan dengan tantangan revolusi industri 4.0 yang bertumpu pada cyber-physical system, sekolah dasar harus menghadirkan sumber daya manusia yang unggul, kompetitif, dan siap menghadapi era globalisasi. Untuk itu, dinas pendidikan Kabupaten/Kota hendaknya melakukan pembinaan dan pelatihan untuk penguatan SDM sekolah pada aspek kompetensi dasar kurikulum, konsep pembelajaran berbasis digital, kepemimpinan, dan pengelolaan pendidikan di sekolah berbasis digital. Pihak pemerintah daerah juga hendaknya memberi dukungan nyata terhadap konsep Merdeka Belajar dengan mempersiapkan infrastruktur dalam menyelenggarakan kurikulum pendidikan 4.0. dan penguatan pengelolaan pendidikan di sekolah berbasis digital secara bertahap dan terencana. Dukungan tersebut dapat dilakukan melalui kebijakan pada Anggaran Pendapatan dan Belanja Daerah (APBD) Kabupaten/Kota untuk pendanaan penyediaan jaringan internet yang stabil dan berkecepatan tinggi, pembelajaran berbasis digital, dan peningkatan kompetensi guru yang profesional dan berkualitas.

\section{PUSTAKA ACUAN}

Alawiyah, F. (2018). Problematika tata kelola guru dalam implementasi undang-undang guru dan dosen. Aspirasi: Jurnal Masalah-Masalah Sosial, 9(1),118-140. https://doi.org/https:// doi.org/10.46807/aspirasi.v9i1.1011.

Arsyad, A. \& Salahudin, S. (2018). Hubungan kemampuan membaca Al Qur'an dan minat belajar siswa dengan hasil belajar Pendidikan Agama Islam (PAI). EDUKASI: Jurnal Penelitian Pendidikan Agama Dan Keagamaan, 16(2), 179-190. https://doi.org/10.32729/ edukasi.v16i2.476.

A. Muri Yusuf. (2013). Metode penelitian kuantitatif, kualitatif, dan penelitian gabungan. Padang: UNP Press.

Badarudin, B. (2019). Peran kepala sekolah dasar dalam mempersiapkan sumber daya pendidik 
menghadapi implementasi Kurikulum 2013. Dinamika Jurnal Ilmiah Pendidikan Dasar, 10(2), 74-84. https://doi.org/10.30595/dinamika.v10i2.3945.

Kementerian Pendidikan dan Kebudayaan. (2016). Peraturan Menteri Pendidikan dan Kebudayaan Republik Indonesia Nomor 75 Tahun 2016 Tentang Komite Sekolah.

Kementerian Pendidikan Nasional. (2007). Peraturan Menteri Pendidikan Nasional Republik Indonesia Nomor 19 Tahun 2007 Tentang Standar Pengelolaan Pendidikan Oleh Satuan Pendidikan Dasar dan Menengah.

Kementerian Pendidikan dan Kebudaayaan. (2018). Distribusi sub indikator standar pengelolaan di SD. Direktorat Pembinaan Sekolah Dasar Kemendikbud RI.

Kementerian Pendidikan dan Kebudaayaan. (2018). Indeks Mutu Sekolah Dasar Beberapa Propinsi. Direktorat Pembinaan Sekolah Dasar Kemendikbud RI.

Mistrianingsih, S., Imron, A., \& Nurabadi, A. (2016). Peran kepala sekolah dalam implementasi manajemen berbasis sekolah. Jurnal Manajemen Pendidikan, 24(5), 367-375. http:// ap.fip.um.ac.id/wp-content/uploads/2015/05/Jurnal-Manajemen-Pendidikan-volume-24no.-5.pdf\#page $=15$.

Palettei, D.A. \& Sulfemi, W.B. (2019). Pengaruh Kelompok Kerja Guru (KKG) terhadap peningkatan kompetensi pedagogik dan kemampuan menulis karya ilmiah. JPDI: Jurnal Pendidikan Dasar Indonesia, 4(2), 53-58. https://doi.org/10.26737/jpdi.v4i2.1522.

Priatna, A. (2018). Manajemen pengembangan mutu sekolah. Jurnal Administrasi Pendidikan, 25(1), 80-90. https://doi.org/10.17509/jap.v25i1.11575

Raharjo, S.B., Yuliana, L., \& Yudha, Y.H. (2018). Capaian standar nasional pendidikan sebagai prediktor mutu sekolah. Jurnal Pendidikan Dan Kebudayaan, 3(2), 129-140.

Sukaningtyas, D., Satori, D., \& Sa'ud, U. S. (2017). Pengembangan kapasitas manajemen sekolah dalam membangun pemahaman visi dan misi. Jurnal Cakrawala Pendidikan, 36(2), 101-107. https://doi.org/10.21831/cp.v36i2.11844.

Sudjiono, A. (2012). Pengantar statistik pendidikan. Jakarta: RajaGrafindo Persada.

Sugiyono. (2013). Metode penelitian kuantitatif kualitatif dan R\&D. Bandung: Alfabeta.

Sulfemi, W.B. (2020). Pengaruh rasa percaya diri dan gaya kepemimpinan kepala sekolah terhadap kinerja guru. Nidhomul Haq/ : Jurnal Manajemen Pendidikan Islam, 5(2), 157179. https://doi.org/10.31538/ndh.v5i2.557.

Sulfemi, W.B. \& Kamalia, Y. (2020). Jigsaw cooperative learning model using audiovisual media to improve learning outcomes. Jurnal Pendidikan Sekolah Dasar, 6(1), 30-42. https://doi.org/ http://dx.doi.org/10.30870/jpsd.v6i1.4919.g5063.

Sulfemi, W.B. \& Mayasari, N. (2019). The use of audio visual media in value clarification technique to improve student learning outcomes in social studies. Jurnal Pendidikan, 20(1), 53-68. https://doi.org/https://doi.org/10.33830/jp.v20i1.235.2019.

Sulfemi, W.B. \& Yuliani, N. (2019). Model pembelajaran contextual teaching and learning (CTL) berbantu media miniatur lingkungan untuk meningkatkan hasil belajar IPS. Edunomic Jurnal Pendidikan Ekonomi, 7(2), 73. https://doi.org/10.33603/ejpe.v7i2.1970.

Yuliana, L. \& Raharjo, S. B. (2019). Ketercapaian standar nasional pendidikan di sekolah menengah atas. Jurnal Pendidikan Dan Kebudayaan, 4(2), 197. https://doi.org/10.24832/ jpnk.v4i2.1457. 